\title{
Effects of Nitrogen and Carbon Application on Maize Output in Ntcheu and Dedza Districts of Central Malawi
}

\author{
Julius H. Mangisoni ${ }^{1 *} \quad$ Thomas S. Jayne ${ }^{2} \quad$ Mike Chigowo $^{3}$ \\ 1.Department of Agricultural and Applied Economics, Bunda College, Lilongwe University of Agriculture and \\ Natural Resources (LUANAR), P.O. Box 219, Lilongwe, Malawi \\ 2.Department of Agricultural, Food and Resource Economics, Michigan State University, East Lansing, USA \\ 3.Department of Nutrition, HIV and AIDS, Private Bag B401, Lilongwe, Malawi
}

\begin{abstract}
This paper uses a translog stochastic frontier model to estimate the relationship between maize yield and an interplay of soil carbon, soil nitrogen and inorganic nitrogen fertilizer using plot-level data collected from smallholder farmers in Dedza and Ntcheu Districts of Malawi in 2013/2014 growing season. One of the covariates in the model is nitrogen applied to a plot from inorganic fertilizers. Farmer use of nitrogen is influenced through participation in a non-random targeted Farm Inputs Subsidy Program (FISP) of the Malawi Government. A control function approach is therefore applied to correct for possible endogeneity of participation in the FISP.Results show that inorganic nitrogen fertilizer has significant positive effect on maize output whereas an increase in soil carbon is associated with low maize output but interaction between soil carbon and soil nitrogen as well as with inorganic nitrogen significantly increases maize output. These results seem to be linked to Carbon to Nitrogen $(\mathrm{C}: \mathrm{N})$ ratio in the soil. The accumulation of $\mathrm{C}$ beyond the optimal $\mathrm{C}: \mathrm{N}$ ratio is known to reduce rate of decomposition, nutrient cycling, shoot: root ratio and biomass in grasses including maize. Under such circumstances, increasing nitrogen brings the $\mathrm{C}: \mathrm{N}$ ratio to beneficial levels. The results further show that inorganic nitrogen is a substitute to labour, seed and land. The substitution relationship suggests that improvements in inorganic nitrogen require reduction in labour, seed use and land. It has further been shown that only $45.03 \%$ of the plots have marginal value cost ratios of greater than one which shows that considerable number of plots are not profitable. For $66.20 \%$ of the plots, applied inorganic nitrogen fertilizer exceeds optimal levels signifying suboptimal use of the input. The results suggest that inorganic nitrogen is profitable at low levels of application which is largely due to prevailing high nitrogen-maize price ratio. The prominent issue for policy consideration from these results is that soils in Malawi are depleted of nitrogen leading to unfavorably high $\mathrm{C}: \mathrm{N}$ ratios which negatively impact maize production. Given that nitrogen-maize price ratio is already high in Malawi, farmers will need programs that enhance their access to nitrogen fertilizers at low prices for nitrogen fertilizer application to be profitable. Such programs need to be implemented simultaneously with a package of intensification practices that fix and retain nitrogen in the soil.

Keywords: Inorganic nitrogen, Soil carbon, Soil nitrogen, Translog stochastic frontier model, Control function approach
\end{abstract}

DOI: $10.7176 / \mathrm{JESD} / 11-2-04$

Publication date: January $31^{\text {st }} 2020$

\section{Introduction}

It is widely believed that sustainable agricultural productivity growth in sub-Saharan Africa will require much greater usage of inorganic fertilizer and improved seed, along with management practices that maintain and improve soil fertility (Snapp et al., 2014, Chianu et al., 2012). Nevertheless, limited use of nutrient inputs, gaseous losses, soil erosion and the general soil land degradation in the region present a fundamental food production challenge (Muyayabantu et al., 2012). Thus, meeting food demand for the growing population has remained an integral part of research and development agenda in the region.

In Malawi, maize is grown on $70 \%$ of smallholder land and is primarily for consumption, with only $15 \%$ sold on the market (MoAFS, 2011; Jayne et al., 2010). Land holdings are very small, with over $80 \%$ below one hectare of land, and are continuing to fragment due to population growth, sub-divisions, and conversion of farmland to housing and other uses. In this environment, agricultural productivity growth will require greater concentration of inputs and soil-augmenting practices to achieve sustainable increases in productivity (Chirwa, 2005; Katengeza et al., 2012; Smale, 1995).

Efficient use of fertilizer potentially enhances agricultural productivity (Dittoh et al., 2012) but in Malawi its gainful use is hindered by diverse factors. For instance, high retail fertilizer prices have excluded most poor smallholder farmers from accessing inorganic fertilizers (IFDC, 2013). Furthermore, despite the country having heterogeneous biophysical and ecological conditions, fertilizer application rates for various crops are based on generalized recommendation (Mutegi et al., 2015). Such factors limit potential of farmers to optimize crop production even if inorganic fertilizer is used.

To improve smallholder maize yields, the Malawi Government has been implementing various forms of fertilizer subsidy programs for over two decades. It is however not clear whether current levels of fertilizer use 
can be sustained without continued subsidization. The evidence is mixed but some studies show that smallholder farmers get highly variable crop response to fertilizer application, which points to varying profitability of fertilizer across farm households and limited demand for fertilizer when obtained at commercial market prices (Snapp et al., 2014; Dorward et al., 2008). Evidence from the crop science and agronomy literature indicates that crop response to fertilizer (and hence its profitability) depends on soil characteristics that are highly influenced by the continuous adoption of integrated soil fertility management practices (Snapp et al., 2014).

To guide policy decisions in a backdrop of fertilizer use challenges, there is growing need to understand how productivity relates to soil nutrients and nutrients supplied through application of inorganic fertilizers. However, a gap in empirical evidence exists on such yield-input relationship with respect to maize and other key food security crops in Malawi. Studies have focused on general effects of subsidy fertilizer on yield (Ricker-Gilbert et al., 2009; Chibwana et al., 2014; Holden, 2013) or on the general effect of fertilizer input on yield within a production frontier framework (Tchale, 2009; Tchale and Sauer, 2007; Simwaka et al., 2013).

As Whitbread et al. (2013) noted, few studies have examined maize yield responses to nitrogen under farmer managed conditions. This paper presents an assessment of the effect of soil carbon, nitrogen, both from inorganic fertilizer sources and from the soil (soil nitrogen), and the interaction effect of carbon and nitrogen on maize yield. Analysis follows control function approach to address the endogeneity of nitrogen from subsidized fertilizer input. Estimation of a stochastic production frontier within an econometric framework that controls for endogeneity, is a first application to the assessment of the effects of nutrient use on maize yield in Malawi.

The rest of paper is organized as follows: Section 2 presents a review of literature on maize productivity. A theoretical model, which is the basis of the analytical model for the study, is covered in Section 3. Section 4 outlines the empirical model, while Section 5 describes the data. The results of the analysis are presented in Section 6 before presenting conclusion and recommendations in Section 7.

\section{Literature Review on Maize Productivity}

In most soils, the use of inorganic nitrogen and phosphorus fertilizers as well as the application of organic fertilizers such as farm yard manure increase maize yield (Oad et al., 2014; Ademba, 2009; Ademba et al., 2015; Mutegi et al., 2012; Nasim et al., 2012). Applied nitrogen reduces the impacts of Striga hermonthica damage to maize yields (Ademba, 2009) and there is evidence that the combination of organic and inorganic fertilizers is superior to the application of organic or inorganic fertilizers separately (Mutegi et al., 2012).

Some studies have shown that inorganic fertilizers alone can improve maize yield (Jiang and Schulthess, 2005; Amin, 2011; Crista et al., 2014; Le Silva et al., 2006; Woldsenbet and Haileyesus 2016) while others have argued that the use of organic fertilizers alone is more superior in enhancing maize yields than inorganic fertilizers. Achieng et al. (2010) found that use of farm yard manure is the best bet for maize production on both Alfisols and Ultisols because there was no significant yield advantage from inorganics over farm yard manure. Supporting this argument, Okonmah (2009) and Boateng et al. (2006) observed that application of poultry manure increases maize yield.

Impact of fertilizers on maize yield is sometimes affected by location factors. In China, Gao et al. (2009) found different yield response rates between northeast, northcentral, and northwest regions with total macronutrient accumulation being higher in the northwest compared to the other two regions. Mugwira et al. (2007) evaluated the effects of manure and inorganic fertilizer on maize growth, yield, and nutrient uptake at Grasslands Research Station and Matiza in Chihota communal area from 1983/84 to 1988/89 as a part of a wider project on sandveld soils in Zimbabwe. The study concluded that feedlot manure was effective in correcting deficiencies of $\mathrm{N}, \mathrm{P}$, or $\mathrm{Mg}$ at the Grasslands. However, application of both manure and inorganic fertilizer had no significant effect on poor status of nutrients of soils at Matiza location.

Ajayi et al. (2005) assessed the effect of fertilizer tree fallows on maize yield in several trials. The study found that apart from increased maize yields, fertilizer tree fallows were more profitable than continuous maize cultivation without fertilizer. However, the fallows were less profitable than fully fertilized plots, especially when the fertilizer was subsidized. The fertilizer tree system is a low-cost investment that requires less labour over its full cycle than other land uses over the same period of time. The results suggested that lasting fertilizer tree fallow systems can generate lasting environmental impacts such as improved soil structure, increased carbon sequestration and reduced cutting of woodlands for fuelwood.

Mango et al. (2015) analyzed technical efficiency of maize production among smallholder farmers in Zimbabwe. The study found that maize output is positively influenced by inorganic fertilizers, seed quantity, the use of labour and area planted. The results also showed that the average efficiency of maize production could be improved by 35 percent through better use of existing resources and technology. Njenga (2013) studied the effect of fertilizer input subsidy on maize production in Wareng District, Kenya. The results indicated that an extra subsidized bag of fertilizer applied increased the number of maize bags produced per acre by 14.3 percent. Access to research and extension services, being a male farmer, access to credit, and use of improved seed (hybrids) increased maize productivity. 


\section{Theoretical Framework}

Smallholder farmers make numerous input allocation decisions in maize production to maximize output given the available inputs and other constraints. The random utility principle underscores the choices farmers make in maize production. A farmer may fail to reach optimal production due to random shock, technical inefficiency or both. Kassie et al. (2014) observed that the agricultural production environment in sub-Saharan Africa, where smallholder farmers operate under uncertainty conditions, requires application of a stochastic production frontier to account for both technical inefficiency and random errors.

This paper takes the stochastic nature of agricultural production into account and applies a control function approach to correct for possible endogeneity of participation in the Malawi Farm Input Subsidy Program (FISP). This is important because the selection of FISP beneficiaries is not random but rather based on some defined criteria (Ricker-Gilbert and Jayne, 2009; Liverpool-Tasie, 2014; Darko and Ricker-Gilbert, 2013; NamonjeKapembwa et al., 2017; Aloyce et al., 2014).

In a production function framework, consider a $k$ th farmer who allocates conventional inputs, $x_{k}$, which along with other productivity shifters, $z_{k}$, affect maize output, $y_{k}$. This relationship in a stochastic production function is specified as:

$$
y_{k}=f\left(x_{k}, z_{k}, \beta\right)+\varepsilon_{k} \text { where } k=1,2, \ldots n \text { and } \varepsilon_{k}=v_{k}-\mu_{k}
$$

In (1), $\beta$ is a vector of unknown parameters to be estimated. The composite error term, ${ }^{\varepsilon_{k}}$, captures unobservable characteristics that affect maize output and has two elements: a symmetrical two sided normally distributed disturbance term $\left({ }^{v_{k}}\right)$ reflecting the stochastic effects that cannot be controlled by a farmer; and an asymmetric non-negative error term ( $\left.\mu_{k}\right)$ which is a one sided ( $\mu_{k} \geq 0$ ) efficiency component for the $k$ th farmer, thus $\varepsilon_{k}=v_{k}-\mu_{k}$ (Battese and Coelli, 1995).

Maize output response associated with additional use of an input is measured by the marginal product of the input which can be derived from (1) by taking partial derivative of $y_{k}$ with respect to $x_{k}$ as follows:

$$
m p_{k j}=\frac{\partial y_{k}}{\partial x_{k j}}
$$

where $m p_{k j}$ is marginal product of input $j$ for a $k$ th farmer and $x_{k j}$ is input $j$ for a $k$ th farmer.

Partial production elasticities of maize output with respect to the inputs can be computed as ratio of marginal product to average product and is defined as:

$$
e_{k j}=\frac{\partial y_{k}}{\partial x_{k j}} * \frac{x_{k j}}{y_{k}}
$$

where $e_{k j}$ is partial output elasticity of a $k$ th farmer with respect to of input $j$. Elasticity of scales, $e s$, which measures returns to scale of the technology can then be computed as the sum of all output elasticities as follows:

$$
\text { es }=\sum e_{k j}
$$

Technical similarity of factors of production in (1) can be measured by elasticity of substitution which captures degree to which one input can be substituted for another without changing quantity of maize output. Given that input $x_{k h}$ and input $x_{k q}$ are a subset of inputs $j$ defined in (2) and (3), elasticity of substitution, eoshq of the two inputs is defined as:

$$
\operatorname{eos}_{h q}=\frac{\partial x_{k h}}{\partial x_{k q}} * \frac{x_{k q}}{x_{k h}}
$$

where, the expression $\frac{\partial x_{k h}}{\partial x_{k q}}$ is marginal rate of technical substitution between input $x_{k h}$ and input $x_{k q}$.

Optimal level for each input in (1) can be determined as level of the input at the point where marginal value is equal to input cost. At this point, the marginal value-cost ratio is equal to one and a risk neutral farmer registers positive benefits from using the input (Liverpool-Tasie et al., 2017). For a $k$ th farmer, marginal value-cost ratio of $j$ th input is derived as follows:

$$
m v c r_{j}=\frac{p_{y}}{p_{j}} * m p_{k j}
$$

where $m v c r_{j}$ is marginal value-cost ratio, $p_{y}$ is price of maize, $p_{j}$ is price of an input and $m p_{k j}$ is marginal product of a given input as defined in (2).

Given the actual maize output, $y_{k}$, in (1), and the highest predicted maize output for the $k$ th farmer given the available technology, ${ }_{k}^{*}$, the technical efficiency $\left(t e_{k}\right)$ of an individual farmer is computed as: 


$$
t e_{k}=\frac{y_{k}}{y_{k}^{*}}=\frac{f\left(x_{k}, z_{k}, \beta\right) \exp \left(v_{k}-\mu_{k}\right)}{f\left(x_{k}, z_{k}, \beta\right) \exp \left(v_{k}\right)}=\exp \left(-\mu_{k}\right)
$$

where parameters $x_{k}, \mathrm{z}_{k}, \beta, v_{k}$ and ${ }^{\mu}{ }_{k}$ are as defined in (1). te $e_{k}$ has values between 0 and 1 and a farm is technically efficient when $t e=1$. Based on Battese and Coelli (1995), maize output gap in terms of technical inefficiency and its determinants is expressed as follows:

$$
\mu_{k}=f\left(T_{k}, \delta\right)+\xi_{k}
$$

where $T_{k}$ is a vector of covariates explaining technical inefficiency, $\delta$ is vector of unknown parameters to be estimated and $\xi_{k}$ is error term.

For consistent estimation of stochastic production frontier (Equation 1), the assumption that explanatory variables $x_{k}$ and $z_{k}$ are exogenously determined must hold (Amsler et al., 2014). One of the covariates in this study is nitrogen from inorganic sources, which is accessed through participation in FISP thereby potentially violating this assumption. To correct for this endogeneity, a control function approach following Darko and Ricker-Gilbert (2013) and Namonje-Kapembwa et al. (2017) was employed.

The estimation procedure entailed inclusion of residuals computed from auxiliary model of participation among the factors explaining technical inefficiency in (8). A probit auxiliary model was used to analyze the two possible alternatives of either participating or not participating in FISP. The conditional probability, Pr, of the probit model, given binary outcome, $S$, for participation in FISP is as follows:

$$
\operatorname{Pr}\left(S_{k}=1 \mid H\right)=f\left(H_{k}{ }^{\prime} \varphi\right)
$$

where $H_{k}$ is a vector of explanatory variables including exclusion factors and covariates, $T_{k}$ is defined in (8) and $\varphi$ is a vector of parameters to be estimated. The model in (9) is non-linear and is estimated through maximum likelihood procedure as follows:

$$
S_{k}=f\left(H_{k}{ }^{\prime} \varphi\right)+\epsilon_{k}
$$

where $\epsilon_{k}$ is an error term with mean zero and independently and normally distributed. Computed residuals, $\Gamma_{k}$, from Equation (10) are included among explanatory variables in the inefficiency model to control for endogeneity. Thus, (8) is redefined as:

$$
\mu_{k}=f\left(T_{k}, \Gamma_{k}, \delta\right)+\xi_{k}
$$

Standard errors are adjusted for the two-step procedure through bootstrapping because the conventionallycalculated standard errors from the Step 2 estimation are incorrect (Bezu et al., 2013; Amsler et al., 2014).

\section{The Empirical Model}

A translog stochastic frontier model was specified to estimate the relationship between maize output and an interplay of soil carbon, soil nitrogen and inorganic nitrogen fertilizer. Unlike a linear production function, the translog production function flexibly measures interaction effects of inputs. Three functions were estimated using the maximum likelihood technique to analyze sensitivity of findings to model specification. Model 1 estimated equations (1) and (7) jointly without correcting for endogeneity of participating in FISP which is controlled in the other two models. Models 2 and 3 estimated (1) and (11) using conventionally-calculated and bootstrapped standard errors, respectively. The estimated frontier function is specified as:

$$
\operatorname{lny}_{k}=\beta_{0}+\sum_{k=1}^{K} \beta_{k} \ln \left(x_{k}\right)+\frac{1}{2} \sum_{k}^{K-1} \sum_{i=k+1}^{K} \rho_{k i} \ln \left(x_{k}\right) \ln \left(x_{i}\right)+\sum_{w=1}^{W} \phi_{w} z_{w}+\varepsilon_{k}
$$

where $y_{k}$ is maize output $(\mathrm{kg})$ and $x_{k}$ constitutes the following conventional inputs: inorganic nitrogen fertilizer $(\mathrm{kg})$, labour (labour-days), maize seed (kg) and farming plot (ha). Factors included in vector of productivity shifters, $z_{w}$, are soil nitrogen (\%), soil active carbon (\%), location dummies for Linthipe, Golomoti and Kandeu Extension Planning Areas, an interaction term for soil nitrogen and soil carbon, and an interaction term for inorganic nitrogen fertilizer and soil carbon. $\beta_{k}, \rho_{k i}$, and $\phi_{w}$ are parameters to be estimated for linear inputs, quadratic and interaction inputs, and other productivity shifters, respectively. The error term $\varepsilon_{k}$ is as defined in (1).

Following Abdulai et al. (2013), all conventional input variables used in the analysis were mean-centered. Inorganic nitrogen fertilizer had zero values in some observations due to non-use of the input as such their corresponding log transformed values were undefined. Following Battese (1997), such zero values were replaced by unities and a dummy variable for fertilizer use was introduced in vector $z_{w}$ to correct for bias arising from substitution of the zero values and thereby obtain correct parameter estimates. This approach allows estimation of a production function from which elasticities of inputs with true zero values can be derived. Inorganic fertilizer 
quantities were converted to milligram before replacing the zeros to ensure that the imputed values are not very close to or exceed any reported quantity. The model was estimated using the converted values but interpretation is in kilogram for it is a commonly used unit of measurement for fertilizer in Malawi.

From the estimated production function, the partial elasticity of production, $e_{k j}$, derived from (12) is given in (13). Elasticity of scale was accordingly derived as sum of all partial output elasticities.

$$
e_{k j}=\frac{\partial \ln y_{k}}{\partial \ln x_{k j}}=\beta_{j}+\sum_{i=1}^{n} \beta_{j i} \ln \left(x_{j}\right)
$$

Elasticity of substitution for a pair of inputs measures the curvature of an isoquant. According to Stern (2008), Allen-Uzawa Elasticity of Substitution is the most commonly used and is adopted in this study. The Allen-Uzawa elasticities of substitution is derived from (12) as follows:

$$
\text { aue }_{h q}=\frac{\sum x_{h}\left(\frac{\partial y_{k}}{\partial x_{k h}}\right)}{x_{h} x_{q}} * \frac{\left|H_{h q}\right|}{H}
$$

where aue $_{h q}$ is Allen-Uzawa Partial elasticity of substitution between inputs $h$ and $q, H_{h q}$ is the cofactor determinant of Hessian matrix for inputs $h$ and $q$, and $H$ is the border determinant of the Hessian matrix.

Marginal products, $m p_{k j}$, with respect to input quantities are derived from (12) based on the output elasticities in (13) as follows:

$$
m p_{k j}=\frac{y_{k}}{x_{k j}} * \frac{\partial \ln y_{k}}{\partial x_{k j}}=\frac{y_{k}}{x_{k j}} *\left(\beta_{j}+\sum_{i=1}^{n} \beta_{j i} \ln \left(x_{j}\right)\right)
$$

The marginal product of inorganic nitrogen fertilizer was used to determine the marginal value-cost ratio of the input. The point at which the ratio is equal to one was also computed accordingly.

Theoretical consistency with production theory requires fulfillment of monotonicity and quasi-concavity conditions for all inputs. For monotonicity condition to be satisfied, marginal product should be positive which implies positive partial production elasticities as well. Quasi-concavity condition is attained for negative semidefinite hessian matrix denoting that the leading principal minors of odd order are negative and of even order are positive. In practice a translog production function does not globally meet the two conditions but the model is assumed to behave appropriately if wide enough regions in input space satisfy the two regularity conditions (Corbo and Meller, 1979).

Translog loses its flexibility if concavity restrictions are imposed globally and hence restrictions are imposed at a particular reference point (Baum and Linz, 2009). Henningsen and Henning (2009) noted that attainment of a quasi-concave production function in practice may be deficient of a technical rational because of two factors. First, inputs are not perfectly divisible and production activities are not independently applicable as quasi-concavity conditions assume. Second, a household or a firm may maximize output given inputs rather than maximizing profits.

The inefficiency term in the translog production function is assumed to be independently distributed and follow an exponential distribution with mean, ${ }^{\mu}$, and variance, ${ }_{u}^{2} \cdot$ An inefficiency model as defined in (11) was estimated as follows:

$$
\mu_{k}=\delta_{0}+\sum_{h=1}^{H} \delta_{h} T_{k}+\delta_{r} \Gamma
$$

where covariates in vector $T_{k}$ are proportion of productive female household members, children under ten years of age, dummy for marital status, dummy for hired labour, remittances received by a household, ownership of bicycle, ownership of phone, head managed plot, spouse managed plot, perceived plot fertility and years of farming on a plot. The factor, $\Gamma$, is a generalized residual from probit auxiliary model as identified in (10). All covariates in (16) were included in the probit plus two exclusion variables: dummies for permanence of residence over last 12 months and distance to fertilizer market.

\section{Data and Variable Description}

The analysis utilized plot-level data collected from smallholder farmers in Dedza and Ntcheu Districts of Malawi in the 2013/2014 growing season. The data was collected within the catchment area of Africa Rising Project which was being implemented to promote use of Integrated Soil Fertility Management (ISFM) practices. The two districts of Dedza and Ntcheu fall within semi-arid to sub-humid tropical agro-ecological zones. Their soils are predominantly sandy loam, well drained, moderately fertile and acidic, and prone to soil erosion. The average annual rainfall varies between 700 and $1100 \mathrm{~mm}$ and is mainly received from December to March with some minor rainfall in November and April. Maize-based production systems are dominant in the two districts.

A structured questionnaire was used to purposefully collect data from households taking into account 
differences in the ecological zones following a stratified random sampling procedure. The survey targeted Mtakataka, Linthipe and Golomoti Extension Planning Areas (EPAs) of Dedza District, and Kandeu and Nsipe EPAs of Ntcheu District. The survey generated rich data on cropping systems, input usage, and household socioeconomic characteristics. This paper focuses on plots with maize. Observations with other main crops were therefore dropped. Likewise, observations with missing or invalid data were also dropped, resulting in a total of 213 observations used for the analysis.

In estimating the translog production frontier model, harvesting labour was excluded from the analysis because it does not directly affect crop productivity. Liu (2006) noted that inclusion of environmental factors may control biases in the production frontier. For this reason, soil carbon and soil nitrogen, the two factors with direct link to the study's objective, were included in the analysis to represent environmental factors while locational dummies were included as proxies for spatial agro-climatic differences (Mignouna et al., 2010; Tchale, 2009).

Exclusion variables in the probit analysis were selected based on a principle underlined by similar studies that used sociopolitical and wealth indicators as instruments in relationships between subsidy fertilizer and production outcomes. For example, Aloyce et al. (2014) used length of residence in the village, accessibility to a village, and wealth situation of the household as exclusion variables when estimating an auxiliary model for subsidy fertilizer. Bezu et al. (2013) and Ricker-Gilbert and Jayne (2009) used number of years the household lived in the village and a member of parliament residing in the community as instruments that proxy social capital which may influence access to input subsidy. The instruments in this study are assumed to significantly correlate with access to subsidy fertilizer but not have direct influence on maize productivity. Validity of the instruments was tested using Durbin-Wu-Hausman test for endogeneity. Description of variables used in the analysis and their summary statistics are given in Table 1.

Table 1: Summary Statistics of the Variables Used in the Stochastic Production Frontier

\begin{tabular}{|l|l|l|l|}
\hline Variable & Description & Mean & Std. Dev. \\
\hline Maize output & Maize output (kg) & 420.804 & 394.200 \\
\hline Inorganic nitrogen fertilizer & Nitrogen from inorganic fertilizer (kg) & 26.048 & 68.656 \\
\hline Labour & Household and hired labour (labour-days) & 52.634 & 40.120 \\
\hline Seed & Amount of seed (kg) & 6.855 & 5.530 \\
\hline Farming plot & Farm plot size (ha) & 0.224 & 0.189 \\
\hline Soil carbon & Percentage carbon in the soil (\%) & 1.296 & 0.564 \\
\hline Soil nitrogen & Percentage nitrogen in the soil (\%) & 0.108 & 0.035 \\
\hline $\begin{array}{l}\text { Inorganic fertilizer use } \\
\text { dummy }\end{array}$ & Dummy (1 = use of inorganic fertilizer, 0 = otherwise) & 0.709 & 0.455 \\
\hline Linthipe & Dummy (1 = Linthipe EPA, 0 = otherwise) & 0.164 & 0.371 \\
\hline Kandeu & Dummy (1 = Kandeu EPA, 0 = otherwise) & 0.244 & 0.431 \\
\hline Golomoti & Dummy (1 = Golomoti EPA, 0 = otherwise) & 0.108 & 0.311 \\
\hline
\end{tabular}

\section{Results and Discussion}

6.1 Diagnostic Test of the Model

Adequacy of the translog production frontier in representing data was tested using a generalized likelihood-ratio (LR) test. The test was implemented under the null hypothesis that a Cobb Douglas model better fits the data compared to a translog production function. This was rejected (Prob $>$ chi2 $=0.0836$ ), signifying that the translog production frontier function represents the data. The null hypothesis that technical inefficiency effects are absent in the estimated model was also tested using LR test and was equally rejected (Prob $>$ chi2 $=5.328 e-14)$. Thus, there was no significant evidence supporting the choice of an average response function over a model which takes into account inefficiency effects in maize production.

Strict monotonicity and quasi-concavity were fulfilled for $86.85 \%$ and $85.92 \%$ of the sample points which suggests that the estimated model is largely consistent with theoretical assumptions underlining a typical production function. Breusch-Pagan test for heteroscedasticity showed that the null hypothesis that there is homoscedasticity cannot be rejected $($ Prob $>$ chi2 $=0.9350)$. The mean Variance Inflation Factor of 9.27 gives an indication that multicollinearity is within tolerable levels. Durbin-Wu-Hausman test for endogeneity failed to reject a null hypothesis that use of subsidized fertilizer is endogenous in the production frontier (Prob $>$ chi2 $=0.0565)$. Function control approach was accordingly employed to correct for the endogeneity. In this two-step estimation technique, generalized residuals from probit auxiliary model were included as regressors in the inefficiency model which was jointly estimated with the frontier model. Results of this analysis are not presented in this paper but are available from the author on request.

\subsection{Econometric Results of the Translog Production Frontier}

The three estimated production functions are presented in Table 2. Results for model 1 were not adjusted for 
endogeneity of participating in FISP. Endogeneity was corrected in models 2 and 3 through control function approach but standard errors were bootstrapped only in model 3 at 1100 repetitions. Amsler et al. (2014) recommended bootstrapping standard errors in such two-step estimation. We present all the three models for comparison purposes. However, our discussion in this paper focuses on model 3 because its standard errors are bootstrapped. Effects of estimated parameters are consistent across the three models but significance levels vary. This suggests that results would be different if the study did not follow control function approach and standard errors were not bootstrapped.

Table 2: Translog Stochastic Frontier Estimates

\begin{tabular}{|c|c|c|c|}
\hline Variable & Model 1 & Model 2 & Model 3 \\
\hline Log of inorganic nitrogen fertilizer & $\begin{array}{l}0.1014 * * \\
(0.0464) \\
\end{array}$ & $\begin{array}{l}0.1019 * * \\
(0.0463) \\
\end{array}$ & $\begin{array}{l}0.1019 * \\
(0.0596)\end{array}$ \\
\hline Log of labor & $\begin{array}{l}0.1478^{*} \\
(0.0799)\end{array}$ & $\begin{array}{l}0.1490 * \\
(0.0799)\end{array}$ & $\begin{array}{l}0.1490 * \\
(0.0882)\end{array}$ \\
\hline Log of seed & $\begin{array}{l}0.1507 * \\
(0.0840)\end{array}$ & $\begin{array}{l}0.1473 * \\
(0.0827)\end{array}$ & $\begin{array}{l}0.1473 \\
(0.0947) \\
\end{array}$ \\
\hline Log of farming plot & $\begin{array}{l}0.4125 * * * \\
(0.0870)\end{array}$ & $\begin{array}{l}0.4159 * * * \\
(0.0865)\end{array}$ & $\begin{array}{l}0.4159 * * * \\
(0.1130)\end{array}$ \\
\hline Log of labor squared & $\begin{array}{l}-0.0203 \\
(0.0598)\end{array}$ & $\begin{array}{l}-0.0203 \\
(0.0596)\end{array}$ & $\begin{array}{l}-0.0203 \\
(0.0722)\end{array}$ \\
\hline Log of seed squared & $\begin{array}{l}0.0371 \\
(0.0407)\end{array}$ & $\begin{array}{l}0.0378 \\
(0.0408)\end{array}$ & $\begin{array}{l}0.0378 \\
(0.0553)\end{array}$ \\
\hline Log of farming plot squared & $\begin{array}{l}-0.0832 * * * \\
(0.0319)\end{array}$ & $\begin{array}{l}-0.0837 * * * \\
(0.0319)\end{array}$ & $\begin{array}{l}-0.0837 * \\
(0.0447)\end{array}$ \\
\hline Log of inorganic nitrogen fertilizer X $\log$ of labor & $\begin{array}{l}-0.0338 \\
(0.0303)\end{array}$ & $\begin{array}{l}-0.0353 \\
(0.0302)\end{array}$ & $\begin{array}{l}-0.0353 \\
(0.0333) \\
\end{array}$ \\
\hline Log of inorganic nitrogen fertilizer $X \log$ of farming plot & $\begin{array}{l}0.0422 * \\
(0.0255) \\
\end{array}$ & $\begin{array}{r}0.0435^{*} \\
(0.0255) \\
\end{array}$ & $\begin{array}{l}0.0435 \\
(0.0310) \\
\end{array}$ \\
\hline Soil carbon & $\begin{array}{l}-0.6949 * * \\
(0.3440)\end{array}$ & $\begin{array}{l}-0.6649 * \\
(0.3424)\end{array}$ & $\begin{array}{l}-0.6649 * \\
(0.3882)\end{array}$ \\
\hline Soil nitrogen & $\begin{array}{l}-1.8860 \\
(4.8461)\end{array}$ & $\begin{array}{l}-2.3211 \\
(4.8354)\end{array}$ & $\begin{array}{l}-2.3211 \\
(5.5347)\end{array}$ \\
\hline Soil nitrogen $\mathrm{X}$ soil carbon & $\begin{array}{l}4.2179^{* *} \\
(1.7034)\end{array}$ & $\begin{array}{l}4.2537 * * \\
(1.7014)\end{array}$ & $\begin{array}{l}4.2537 * * \\
(1.8299)\end{array}$ \\
\hline Log of inorganic nitrogen fertilizer X log soil carbon & $\begin{array}{l}0.0399 * * \\
(0.0177)\end{array}$ & $\begin{array}{l}0.0410 * * \\
(0.0177)\end{array}$ & $\begin{array}{l}0.0410 * * \\
(0.0204) \\
\end{array}$ \\
\hline Inorganic fertilizer use & $\begin{array}{l}-1.2494 * * * \\
(0.4287)\end{array}$ & $\begin{array}{l}-1.2629 * * * \\
(0.4280)\end{array}$ & $\begin{array}{l}-1.2629 * * \\
(0.5589) \\
\end{array}$ \\
\hline Linthipe & $\begin{array}{l}0.5966^{* * * *} \\
(0.1475)\end{array}$ & $\begin{array}{l}0.5716^{* * * *} \\
(0.1455)\end{array}$ & $\begin{array}{l}0.5716^{* * * *} \\
(0.1985)\end{array}$ \\
\hline Kandeu & $\begin{array}{l}0.2666 * * \\
(0.1048)\end{array}$ & $\begin{array}{l}0.2787 * * * \\
(0.1052)\end{array}$ & $\begin{array}{l}0.2787 \\
(0.1775)\end{array}$ \\
\hline Golomoti & $\begin{array}{l}0.1083 \\
(0.1374) \\
\end{array}$ & $\begin{array}{l}0.0909 \\
(0.1353) \\
\end{array}$ & $\begin{array}{l}0.0909 \\
(0.1816) \\
\end{array}$ \\
\hline Intercept & $\begin{array}{l}1.8868 * * * \\
(0.4875) \\
\end{array}$ & $\begin{array}{l}1.9123 * * * \\
(0.4860) \\
\end{array}$ & $\begin{array}{l}1.9123 * * * \\
(0.6290) \\
\end{array}$ \\
\hline Sigma u & 0.3594 & 0.3640 & \\
\hline Sigma $v$ & $\begin{array}{l}0.4864 * * * \\
(0.0413)\end{array}$ & $\begin{array}{l}0.4848 * * * \\
(0.0385) \\
\end{array}$ & $\begin{array}{l}-1.4481^{*} \\
(6.3156) \\
\end{array}$ \\
\hline Wald chi2(17) & 324.1700 & 323.0500 & 196.4200 \\
\hline Prob $>$ chi2 & 0.0000 & 0.0000 & 0.0000 \\
\hline Log likelihood & 187.7799 & 187.6960 & 187.6960 \\
\hline Number of observations & 213 & 213 & 213 \\
\hline \multicolumn{4}{|l|}{ Model Tests } \\
\hline Monotonicity & \multicolumn{3}{|l|}{$86.85 \%$} \\
\hline Quasi-concavity & \multicolumn{3}{|c|}{$85.92 \%$} \\
\hline Function Form test & \multicolumn{3}{|c|}{ chi2(6) $=9.72 ;$ Prob $>$ chi $2=0.0836$} \\
\hline Inefficiency test & \multicolumn{3}{|c|}{$\operatorname{chi2}(1)=56.60 ;$ Prob $>$ chi2 $=5.328 e-14$} \\
\hline Heteroscedasticity test & \multicolumn{3}{|c|}{$\operatorname{chi} 2(1)=0.01 ;$ Prob $>$ chi $2=0.9350$} \\
\hline
\end{tabular}




\begin{tabular}{|l|l|}
\hline Variance Inflation Factor & 9.27 \\
\hline Endogeneity test & chi2 $(1)=3.64 ;$ Prob $>$ chi $2=0.0565$ \\
\hline Standard errors in parentheses & $* * * \mathrm{p}<0.01, * * \mathrm{p}<0.05, * \mathrm{p}<0.1$
\end{tabular}

Among the conventional inputs, inorganic nitrogen fertilizer, labour and farming plot are significant factors that explain variation in maize output. The positive coefficient of inorganic nitrogen fertilizer signifies that the likelihood of having high maize output is greater for farmers using more of the input than those who do not. The results compare favorably with the findings of Dlamini et al. (2012) and Liverpool-Tasie (2017) who observed positive relationship between maize productivity and inorganic fertilizer in Swaziland and Nigeria, respectively. Majority of smallholder farmers in Malawi own small pieces of land which are largely nitrogen deficient (CARD, 2014). Nitrogen content on about 98.12 percent of farming plots in this study is below critical limit of 0.2 percent adopted in a study by Sagona et al. (2016) who analysed physiochemical properties of farming land in three districts of Southern Malawi. Intensified use of nitrogen fertilizer on such plots would present an option for maximizing maize production.

As expected a prior and consistent with Essilfie et al. (2011) and Ayinde et al. (2015), first order parameter estimate on labour is positive and significant at the $10 \%$ level. This implies that using more labour on a farming plot is associated with high maize yield than using less of it. Household labour is one of the key inputs readily available to resource constrained smallholder farmers who have limited access to purchased inputs. Households with adequate labour are able to meet timeliness in all field operations. Shortage of household labour therefore aggravates chronic production deficits among poor households, particularly those with farm sizes of up to 1 hectare who are perennial net food buyers (Devereux 1997; Jayne et al., 2010).

Coefficient of the first order term of farming plot is significant and positively associated with maize output whereas the quadratic term of the same has significant negative effects. Thus, increasing farming plot size would increase maize output to a point where further increase in farming plot size would reduce the output. The inverse relationship between farm size and maize productivity is reported in empirical work of many authors including Liverpool-Tasie et al. (2017). Such relationship is depicted in small farms in China purportedly attributable to use of more labour in place of capital inputs as scale of production increases with land size (Sheng et al., 2019). It was further noted by Restuccia and Santaeulàlia-Llopis (2017) that access to land by more productive farmers in Malawi is constrained by restrictive land markets as land is, to a greater extent, traditionally accessed through inheritance.

Contrary to findings of Matsumoto and Yamano (2009), soil carbon has a significant negative effect on maize output at the $10 \%$ level. Similar findings, however, were reported by Eschen et al. (2006) in Switzerland who found a reduction in shoot biomass in response to increasing levels of carbon in annual species than in perennial species. This was due to a reduction in shoot: root ratio in grasses in response to the addition of carbon that increased C:N ratio to unacceptable and possibly intolerable levels that impede crop productivity. For about 89.67 percent of the farming plots under the study, carbon content is above critical point of 0.7 percent required to support crop production as reported by Snapp (n.d.). This critical point appeared in more recent literature and is comparable to a critical value of 0.8 reported by Snapp (1998). With the low nitrogen content in the soil, C:N ratio may be high on most farming plots and therefore reducing carbon content would reduce the ratio to some tolerable levels that can boost maize production.

Unlike the coefficient on soil carbon, the interaction term of soil nitrogen and soil carbon is positive and significant as expected. This shows that the negative relationship between maize output and soil carbon may indeed be at low levels of soil nitrogen; maize output would increase as soil nitrogen content in the soil exceeds some threshold level and soil carbon simultaneously increases. The interaction between inorganic nitrogen fertilizer and soil carbon is significantly positive which shows that joint increase of the two factors would also increase maize output. In a study by Dong et al. (2012) in China, it was concluded that fertilizer application improves soil fertility by increasing carbon and nitrogen content in the soil with only slight increase in the C:N ratio. Our findings therefore appear to suggest that applied nitrogen fertilizer avails nitrogen in the soil to levels where maize output increases with an increase in soil carbon.

As expected, non-use of inorganic nitrogen fertilizer is negatively associated with maize yield. One location dummy (Linthipe) has significant effect on maize output which suggests the importance of spatial biophysical and ecological factors in maize productivity.

\subsubsection{Elasticities of the Estimated Function}

Partial production elasticities, elasticity of scale and elasticities of substitution computed from the estimated production function are presented in Table 3. Consistent with Essilfie et al. (2011) and Dlamini et al. (2012), mean partial production elasticities for all conventional inputs are less than one and therefore inelastic. It is shown that holding all other factors constant, a percentage increase in inorganic nitrogen fertilizer would increase maize output by about 0.15 percent while a percentage increase in labour, seed and farming plot would result in 0.27 percent, 0.13 percent and 0.30 percent increase in maize output, respectively. These findings suggest that increase in use of the inputs would still shift maize yield towards some optimal achievable levels. 
Output elasticities for soil nitrogen and soil carbon are 3.19 and -0.34 , respectively. This shows that a percentage increase in soil nitrogen would increase maize output by 3.19 percent whereas similar increase in soil carbon would reduce maize output by 0.34 percent. The output elasticity of soil carbon is unexpectedly negative possibly due to low levels of soil nitrogen relative to soil carbon. Empirical evidence from China suggests that soil organic matter decomposition rate is low when $\mathrm{C}: \mathrm{N}$ ratio is high because nitrogen content is not sufficient to sustain the growing population of decomposition bacteria (Shi, 2017). Under such circumstance, application of nitrogen-rich materials such as inorganic nitrogen fertilizer tends to speed decomposition and reduce temporary loss of soil nitrogen to microbial biological activities (Miller, 2000).

Threshold level of soil nitrogen that would yield positive elasticity of soil carbon was estimated for each farming plot. Soil carbon content vary across farming plots with different biophysical properties. As such, soil nitrogen critical values may also differ across plots. It was shown that the elasticity of soil carbon would be positive if nitrogen content on a plot exceeds the average of 0.19 percent. Only 3.76 percent of the farming plots contain soil nitrogen that exceed their threshold level. The estimations are consistent with observation by Mutegi et al. (2015) who noted that nitrogen is a key limiting soil nutrient on most farming plots in Malawi.

Table 3: Distribution of Elasticities

\begin{tabular}{|l|l|l|l|}
\hline Elasticity & Variable & Mean & Std. Dev. \\
\hline \multirow{5}{*}{ Output Elasticity } & Inorganic Nitrogen fertilizer & 0.1492 & 0.0423 \\
\cline { 2 - 4 } & Labour & 0.2721 & 0.1617 \\
\cline { 2 - 4 } & Seed & 0.1351 & 0.0324 \\
\cline { 2 - 4 } & Farming plot & 0.3020 & 0.2021 \\
\cline { 2 - 4 } & Soil carbon & -0.3432 & 0.2209 \\
\cline { 2 - 4 } & Soil nitrogen & 3.1925 & 2.4002 \\
\hline \multirow{5}{*}{ Elasticity of Substitution } & Nitrogen fertilizer and labour & 3.1550 & 2.8099 \\
\cline { 2 - 4 } & Nitrogen fertilizer and seed & 3.2542 & 2.9785 \\
\cline { 2 - 4 } & Nitrogen fertilizer and Farming Plot & 1.4079 & 1.0978 \\
\cline { 2 - 4 } & Labour and seed & 1.4485 & 0.5997 \\
\cline { 2 - 4 } & Labour and Farming Plot & 0.6170 & 4.7382 \\
\cline { 2 - 4 } & Seed and Farming Plot & 4.2614 & 47.0968 \\
\hline Elasticity of Scale & 3.3860 & 2.5362 \\
\hline Soil Nitrogen Threshold Level that Yields Positive Elasticity of Carbon (\%) & 0.1883 & 0.0435 \\
\hline
\end{tabular}

The elasticity of scale is estimated at 3.39 which shows that the farmers in the two study districts of Malawi are producing at increasing returns to scale. The results also show that a percentage increase in each of the inputs would increase maize output by 4.64 percent. Oduntan et al. (2016) observed decreasing return to scale among maize-cowpea farmers in South West Nigeria while Bwala et al. (2015) observed returns to scale of 1.06 in North Central Nigeria in a production frontier that did not control for environmental factors.

Table 3 also presents partial elasticities of substitution for the conventional input pairs. According to Debertin (2012), if a production function has more than two inputs, it is possible for some pairs of the inputs to be substitutes and others complements. For complement pairs, the elasticity of substitution is negative and positive for substitutes. The elasticity of substitution of labour, seed and farming plot for inorganic nitrogen fertilizer are 3.16, 3.25 and 1.41 , respectively. Elasticity of substitution of labour for seed is 1.45 which is higher than elasticity of substitution of labour for land (0.62). Elasticity of substitution of seed for land is 4.26 which shows that the two inputs have the highest substitutability of all conventional input combinations.

\subsubsection{Profitability of Inorganic Nitrogen Fertilizer}

Estimation of the optimal inorganic nitrogen fertilizer requirements considered the marginal product (MP) derived from estimated translog function, average price of inorganic nitrogen fertilizer and market price of maize prevailing in the study area. Table 4 summaries the marginal products for the conventional farm inputs. The marginal product of inorganic nitrogen fertilizer is $7.98 \mathrm{~kg}$, implying that an additional kilogram of inorganic nitrogen fertilizer would yield an increase of $7.98 \mathrm{~kg}$ in maize output, ceteris paribus. The marginal product falls within a range of 0.12 to 17.6 noted by Liverpool-Tasie et al. (2017) with respect to fertilizer in selected African studies. Marginal product of labour is estimated at 3.14 and of seed is 11.44 implying that a unit increase in labour and seed increases maize output by $3.14 \mathrm{~kg}$ and $11.44 \mathrm{~kg}$, respectively. The marginal products reported for seed and labour are comparable to the values estimated by Sauer and Tchale (2009) in Malawi. Land has the highest marginal product of 908.40 which shows that increasing farming plot by a hectare increases maize output by $908.40 \mathrm{~kg}$. 
Table 4: Marginal Product of Inputs

\begin{tabular}{|l|l|l|}
\hline Variable & Mean MP & Std. Dev. \\
\hline Nitrogen fertilizer & 7.9835 & 27.0209 \\
\hline Labour & 3.1419 & 2.5738 \\
\hline Seed & 11.4371 & 5.6413 \\
\hline Farming Plot & 908.4046 & 844.6057 \\
\hline
\end{tabular}

The market prices of fertilizer and maize as reported by farmers averaged MK1 105.48/kg and MK65.93/kg, respectively (Table 5). This gives a high nitrogen-maize price ratio which is in conformity with observation by Edriss et al. (2004) that the ratio is high Malawi. Given the prices, marginal value cost ratio averaged 0.48 for all the plots. The marginal value cost ratio exceeds one on $45.03 \%$ of the plots which shows that use of inorganic nitrogen fertilizer is profitable for risk neutral farmers on these farming plots. However, the proportion of plots with marginal value cost ratios that exceed one may have been even lower if estimation had accounted for transaction and transport costs associated with fertilizer acquisition. The findings are consistent with observation by Snapp et al. (2014) that empirical evidence in Malawi reveals limited profitability or even negative profitability of fertilizer use at commercial price.

Table 5: Marginal Value Product as Ratio of Fertilizer Price

\begin{tabular}{|l|l|l|l|l|}
\hline $\begin{array}{l}\text { Nitrogen Price } \\
\text { (MK/Kg) }\end{array}$ & $\begin{array}{l}\text { Maize Price } \\
\text { (MK/Kg) }\end{array}$ & $\begin{array}{l}\text { Marginal Value Product as ratio of fertilizer } \\
\text { price }\end{array}$ & $\begin{array}{l}\text { Plots MVPR> 1 } \\
\text { (\%) }\end{array}$ \\
\cline { 3 - 4 } & Mean & Std. Dev. & \\
\hline 1105.48 & 65.93 & 0.4761 & 1.6115 & 45.03 \\
\hline
\end{tabular}

Table 6 gives a summary of quantities of inorganic nitrogen fertilizer that optimize maize yield on different plots. Nitrogen fertilizer optimal level averaged $20.01 \mathrm{~kg}$ for all the plots. About $66.20 \%$ of the plots uses inorganic nitrogen fertilizer beyond their respective optimal levels. For $29.11 \%$ of plots, observed inorganic nitrogen fertilizer levels are greater than their average optimal levels. Applying fertilizer beyond optimal levels signifies resource use inefficiencies and potential yield is not reached if applied fertilizer levels are below optimal levels (Amatya et al., 2008). This shows that inorganic nitrogen is profitable at low levels of application for most plots. If levels of inorganic nitrogen fertilizer are higher than the optimal level, profitability will be eroded by high nitrogen-maize price ratio.

\begin{tabular}{|c|c|c|c|}
\hline \multicolumn{2}{|c|}{ Nitrogen fertilizer optimal level } & \multirow{2}{*}{$\begin{array}{l}\text { Plots exceeding their optimal } \\
\text { level }(\%)\end{array}$} & \multirow{2}{*}{$\begin{array}{l}\text { Plots exceeding average optimal } \\
\text { level }(\%)\end{array}$} \\
\hline Mean & Std. Dev. & & \\
\hline 20.0090 & 110.6311 & 66.20 & 29.11 \\
\hline
\end{tabular}

\section{Conclusion and Recommendation}

Farmers' efficient use of natural soil nitrogen and soil carbon as well as nutrients from other sources including inorganic nitrogen fertilizer application can elevate their potential to attain optimal maize output levels. This study has analyzed the effect of nitrogen and carbon on maize output. Both output effects of soil nitrogen and inorganic nitrogen fertilizer were analyzed alongside the effects of active carbon in the soil and other factors of production.

Results show that inorganic nitrogen fertilizer has significant positive effect on maize output whereas an increase in soil carbon is associated with lower maize output. It is further shown that interaction of soil nitrogen and soil carbon significantly increases maize output. These results seem to be linked to $\mathrm{C}: \mathrm{N}$ ratio in the soil. If the $\mathrm{C}: \mathrm{N}$ ratio is too high (high carbon), decomposition occurs slowly and the nitrogen content is not sufficient to sustain the growing population of decomposition bacteria. Thus, any addition of $\mathrm{C}$ makes matters worse by further increasing the ratio and this accumulation of $\mathrm{C}$ is known to reduce shoot: root ratio and biomass in grasses including maize. Under such circumstances, increasing nitrogen brings the $\mathrm{C}: \mathrm{N}$ ratio to beneficial levels. Thus, farming practices that maintain appropriate $\mathrm{C}: \mathrm{N}$ ratios would yield positive effect on maize output.

While for most farming plots (98.12\%) nitrogen content is below the critical limit of 0.2 percent, carbon content on 89.67 percent of the farming plots exceeds critical limit of 0.7 percent. The $\mathrm{C}: \mathrm{N}$ ratio may therefore indeed be high for most farming plots. It is hardly surprising that the average output elasticity of soil nitrogen is positive whereas that of soil carbon is negative. Increasing carbon content further in such scenario may raise the $\mathrm{C}: \mathrm{N}$ ratio to even more intolerable levels. It has been shown that the output elasticity of carbon would have been positive if soil nitrogen was increased in the soil to an average of 0.19 percent. The output elasticity of inorganic nitrogen fertilizer is low (0.15), nevertheless, it suggests that increasing use of the input still shifts maize yield towards some optimal achievable levels. Estimated elasticities of substitution showed varying degree of substitutability between inorganic nitrogen fertilizer and other conventional inputs. The degree of substitutability is higher with respect to labour and seed than farming plot size. Nevertheless, this shows that increased use of inorganic nitrogen fertilizer can be accompanied by reduction in some inputs that farmers use for maize production.

The profitability of inorganic nitrogen fertilizer is shown to be dependent on marginal product of the fertilizer 
and the nitrogen-maize price ratio. At market price, 45.03 percent of farming plots have marginal value cost ratios that exceed one with respect to inorganic nitrogen fertilizer. Furthermore, it is shown that for 66.20 percent of farming plots, inorganic nitrogen fertilizer is used beyond optimal levels. Therefore, the use of inorganic nitrogen fertilizer has been shown to be profitable for some farmers but this is mainly at low levels of fertilizer application as high nitrogen-maize price ratio erodes profitability at high levels of fertilizer application.

As a key issue for recommendation, the study has shown that soils in the study area are depleted of nitrogen as compared to carbon leading to unfavorably high $\mathrm{C}: \mathrm{N}$ ratios which impede maize production. Replenishing the soil with inorganic nitrogen fertilizer is one of the available options under such circumstance but its profitability is constrained by high nitrogen-maize price ratio. Farmers therefore need programs that enhance their access to inorganic nitrogen fertilizers at reasonable prices. Such programs can be implemented simultaneously with a package of intensified agricultural practices that fix and retain nitrogen in the soil.

\section{Acknowledgement}

We would like to recognize Guiding Investments in Sustainable Agricultural Intensification in Africa (GISAIA) of Michigan State University and Africa Rising for supporting the study.

\section{References}

Abdulai, S., Nkegbe, P.K., and Donkoh, S.A. (2013). Technical efficiency of maize production in Northern Ghana. African Journal of Agricultural Research, 8(43), 5251-5259.

Achieng, J.O., Ouma, G., Odhiambo, G. and Muyekho, F. (2010). Effect of farmyard manure and inorganic fertilizers on maize production on Alfisols and Ultisols in Kakamega, western Kenya. Agriculture and biology Journal of North America, 1(4), 430-439.

Ademba, J. S. (2009). Analytical determination of the effects of phosphatic fertilizers and manure on maize yields in acidic soils in Kisil and Rachuonyo districts. A thesis submitted in partial fulfilment of the requirements for the award of Master of Science in chemistry of Egerton University, Kenya.

Ademba, J. S., Kwach, J. K., Esilaba, A. O. and Ngari, S. M. (2015). The effects of phosphate fertilizers and manure on maize yields in South Western Kenya. East African Agricultural and Forestry Journal, 81(1), 111.

Ajayi, O. C., Place, F., Kwesiga, F., Mafongoya, P., and Franzel, S. (2005). Impact of fertilizer tree fallows in Eastern Zambia. World Agroforestry Centre, Nairobi, Kenya.

Aloyce, G.M., Gabagambi, D.M., Hella J.P. (2014). National agricultural input voucher scheme impact on productivity and food security of smallholder farmers in Tanzania. Journal of Economics and Sustainable Development, 5(21), 32-43.

Amatya, P., Yu, M., Ewell, F. (2008). Economic Analysis of Optimal Nitrogen Application in Corn Production. The Texas Journal of Agriculture and Natural Resource, 21,103-110.

Amin, M.E.H. (2011). Effect of different nitrogen sources on growth, yield and quality of fodder maize (Zea mays L.). Journal of the Saudi Society of Agricultural Sciences, 10(1), 17-23.

Amsler, C., Prokhorov, A., and Schmidt, P. (2014). Endogeneity in stochastic frontier models. BA Working Paper No: BAWP-2015-01.

Awunyo-Vitor, D., Wongnaa, C.A., Aidoo, R. (2016). Resource use efficiency among maize farmers in Ghana. Agriculture \& Food Security, 5:28. doi 10.1186/s40066-016-0076-2.

Ayinde, I A., Aminu, R.O., and Ibrahim, S.B. (2015). Technical efficiency of maize production in Ogun State, Nigeria. Journal of Development and Agricultural Economics, 7(2), 55-60.

Battese, G. E., and Coelli, T. J. (1995). A model for technical inefficiency effect in stochastic frontier production for panel data. Empirical Economics, 20, 325-332.

Battese, G.E. (1997). A note on the estimation of Cobb-Douglas production functions when some explanatory variables have zero values. Journal of Agricultural Economics, 48(2), 250 - 252.

Baum, C. F., Linz, T. (2009). Evaluating concavity for production and cost functions. The Stata Journal, 9(1), $161-165$

Bezu, S., and Kassie, G., Shiferaw, B., and and Ricker-Gilbert, J. (2013). Impact of improved maize adoption on welfare of farm households in Malawi: A Panel data analysis. MPRA Paper No. 48763. Available online at https://mpra.ub.uni-muenchen.de/48763/.

Boateng, S. A., Zickermann, J. and Kornahrens, M. (2006). Poultry manure effect on growth and yield of maize. West Africa Journal of Applied Ecology, 9(12 of 18), 1-11.

Bwala, M., Akokoye, H. S. E., and Yegbemey, R. N. (2015). Technical efficiency of cereal production in North Central Nigeria: A Case for maize, rice and sorghum farmers. Journal of Agricultural Science and Environment, 15(1), 25-34.

CARD. (2014). Linkages Between Land, Agricultural Finance, Inputs and Markets: A Contextual Analysis of Malawi's Agricultural Sector with a Focus on Lilongwe, Mchinji and Salima Districts. Lilongwe University 
Of Agriculture And Natural Resources, Lilongwe, Malawi.

Chibwana, C., Shively, G., Fisher. M., Jumbe, C., Masters. W. (2014). Measuring the impacts of Malawi's farm input subsidy programme. African Journal of Agriculture and Resource Economics, 9 (2), 132-147.

Chirwa, E. W. (2005). Adoption of fertiliser and hybrid seeds by smallholder maize farmers in southern Malawi. Development Southern Africa, 22(1), 010001-12.

Corbo, V. And Meller, P. (1979): The translog production function: Some evidence from establishment data. Journal of Econometrics, 10(179), 193-199.

Crista, F., Boldea, M., Radulov, I., Lato, A., Crista, L., Dragomir, C., Berbecea, A., Nita, L. and Okros, A. (2014). The impact of chemical fertilization on maize yield. Research Journal of Agricultural Science, 46 (1), $172-$ 177.

Darko, F.A., and Ricker-Gilbert, J. (2013). Economic efficiency and subsidized farm inputs: Evidence from Malawi maize farmers. Invited paper presented at the 4th International Conference of the African Association of Agricultural Economists, September 22-25, 2013, Hammamet, Tunisia.

Debertin, D.L. (2012). Agricultural production economics. 2nd Edition. Pearson Education, Upper Saddle River, NJ, USA.

Devereux, S. (1997). Household food security in Malawi. Discussion Paper 362. Institute of Development Studies, University of Sussex.

Dittoh, S., Omotosho, O., Belemvire, A., Akuriba, M., and Haider, K. (2012). Improving the effectiveness, efficiency and sustainability of fertilizer use in Sub-Saharan Africa. GDN Agriculture Policy Series. Briefing Paper Number 3.

Dlamini1, S.I., Masuku, M.B., 2and Rugambisa, J. I. (2012). Technical efficiency of maize production in Swaziland: A stochastic frontier approach. African Journal of Agricultural Research, 7(42), 5628-5636.

Dong, W., Zhang, X., Wang, H., Dai, X., Sun, X., Qiu, W., Yang, F. (2012). Effect of Different Fertilizer Application on the Soil Fertility of Paddy Soils in Red Soil Region of Southern China. PLoS ONE, 7(9): e44504. doi:10.1371/journal.pone.0044504.

Dorward, A., Chirwa, E., Boughton D., Crawford, E., Jayne, T., Slater, R., Kelly, V., and Tsoka, M., (2008). Towards Smart Subsidies in Agriculture? Lessons from Recent Experience in Malawi. Natural Resource Perspectives 116: Overseas Development Institute, London, UK.

Edriss, A., Tchale, H., and Wobst, P. 2004. The Impact of Labour Market Liberalization on Maize Productivity and Rural Poverty in Malawi. Project paper. Available at www.researchgate.net/publication/237226326The_Impact_of_Labour_Market_Liberalization_on_Maize_P roductivity_and_Rural_Poverty_in_Malawi1.

Eschen, R., Muller-Scharer, $\bar{H}$ and Schaffner, U. (2006). Soil carbon affects plant growth in a species-specific way. Journal of Applied Ecology, 43 (1), 35-42.

Essilfie, F. L., Asiamah, M.T., and Nimoh, F. (2011). Estimation of farm level technical efficiency in small scale maize production in the Mfantseman Municipality in the Central Region of Ghana: A stochastic frontier approach. Journal of Development and Agricultural Economics, 3(14), 645-654.

Gao, W., Jin, J., He, P., Li, S., Zhu, J. and Li, M. (2009). Optimum fertilization effect on maize yield, nutrient uptake, and utilization in Northern China. Better Crops, 93(2), 18-20.

Henningsen, A., and Henning, H.C.A. (2009). Imposing regional monotonicity on translog stochastic production frontiers with a simple three-step procedure. J Prod Anal, (32), 217-229.

Holden, S. (2013). Amazing maize in Malawi: Input subsidies, factor productivity and land use intensification. Centre for Land Tenure Studies. Working Paper 04/13.

IFDC (2013). Malawi fertilizer assessment. Muscle Shoals, Alabama 35662, USA.

Jayne, T.S., Mather, D. \& Mghenyi, E. (2010). Principal challenges confronting smallholder agriculture in subSaharan Africa. World Development, 38(10), 1384-1398.

Jiang, N. and Schulthess, E. (2005). The effect of nitrogen fertilizer application to maize and sorghum on the bionomics of Chilo partellus (Lepidoptera: Crambidae) and the performance of its larval parasitoid Cotesia flavipes (Hymenoptera: Braconidae). Bull Entomol Res., 95(6), 495-504.

Jonas Chianu, Justina Chianu, Mairura. (2012). Mineral fertilizers in the farming systems of sub-Saharan Africa. A review. Agronomy for Sustainable Development, 32 (2), 545-566.

Kassie, M., Teklewold, H., Marenya, P., Jaleta, M., and Erenstein, O. (2014). Production risks and food security under alternative technology choices in Malawi: Application of a multinomial endogenous switching regression. Journal of Agricultural Economics, 66(3), 640-659.

Katengeza, S. P., Mangisoni, J. H., Kassie, G. T., Sutcliffe, C., Langyintuo, A., La Rovere, R., and Mwangi, W. (2012). Drivers of adoption of improved maize varieties in drought prone areas of Malawi. Journal of Development and Agricultural Economics, 4(14), 393-403.

Le Silva, P. S., da Silva, J., Oliveira, F. H, T., de Sousa, A. K. F. and Duda, G.P. (2006). Residual effect of cattle manure application on green ear yield and corn grain yield. Horticultura Brasileira, 24(2), 166-169. 
Liu, Y. (2006). Model selection in stochastic frontier analysis: Maize production in Kenya. Selected Paper prepared for presentation at the American Agricultural Economics Association Annual Meeting, Long Beach, California, July 23-26, 2006.

Liverpool-Tasie, L. S. O, (2014). Fertilizer subsidies and private market participation: The case of Kano State, Nigeria. Prepared for presentation at the CSAE Conference March 2014.

Liverpool-Tasie, L.S.O., Omonona, B.T., Sanou, A., Ogunleye, W.O. (2017). Is increasing inorganic fertilizer use for maize production in SSA a profitable proposition? Evidence from Nigeria. Food Policy, 67(2017), 41-51.

Mango, N., Makate, C., Mlambo, B. H., Siziba, S. and Lundy, M. (2015). A stochastic frontier analysis of technical efficiency in smallholder maize production in Zimbabwe: The post-fast-track land reform outlook. Journal of Cogent Economics and Finance, 3 (1), 1-14.

Matsumoto, T., and Yamano, T. (2010). Soil Fertility, Fertilizer, and the Maize Green Revolution in East Africa. Policy Research Working Paper 5158. Washington, DC: World Bank.

Mignouna, D.B., Mutabazi, K., Senkondo, E.M., and Manyong, V.M. (2010). Adoption of a new maize and production efficiency in Western Kenya. Contributed Paper presented at the Joint 3rd African Association of Agricultural Economists (AAAE) and 48th Agricultural Economists Association of South Africa (AEASA) Conference, Cape Town, South Africa, September 19-23, 2010.

Miller, C., 2000. Understanding the Carbon-Nitrogen Ratio. Acres U.S.A., 30(4): 20.

MoAFS (2011). Malawi Agricultural Sector Wide Approach: A prioritised and harmonised Agricultural Development Agenda 2011-2015. Lilongwe, Malawi: Ministry of Agriculture and Food Security.

Mugwira, L.M., J. Nyamangara, J. and Hikwa, D. (2007). Effects of manure and fertilizer on maize at a research station and in a smallholder (peasant) area of Zimbabwe. Communications in Soil Science and Plant Analysis, $33(3-4), 379-402$.

Mutegi J, Kabambe V, Zingore S, Harawa R and Wairegi L (2015) The fertilizer recommendation issues in Malawi: Gaps, challenges, opportunities and guidelines. Soil Health Consortium of Malawi.

Mutegi, E.M., Kung'u, J. B., Muna, M., Pieter, P. and Mugendi, D. N. (2012). Complementary effects of organic and mineral fertilizers on maize production in the smallholder farms of Meru South District, Kenya. Agricultural Sciences, 3 (2), 221-229.

Muyayabantu, G.M., Kadiata, B. D., and Nkongolo, K. K. (2012). Response of maize to different organic and inorganic fertilization regimes in monocrop and intercrop systems in a Sub-Saharan Africa Region. Journal of Soil Science and Environmental Management, 3(2), 42-48.

Namonje-Kapembwa, T., Black, R., and Jayne, T.S. (2017). Does late delivery of subsidized fertilizer affect smallholder maize productivity and production? Agricultural Research \& Technology: Open Access Journal, 11(2). https//juniperpublishers.com/artoaj/.

Nasim, W., Ahmad, A., Khaliq, T., Wajid, A., Munis, M. F. H., Chaudhry, H. J., Ahmad, M. M. M. S.M. and Hammad, H. M. (2012). Effect of organic and inorganic fertilizer on maize hybrids under agro-environmental conditions of Faisalabad-Pakistan. African Journal of Agricultural Research, 7(17), 2713-2719.

Njenga, E. (2013). Effect of fertilizer input subsidy on maize production in Kenya: The case of Wareng district. School of Economics, University of Nairobi, Kenya.

Oad, C.F., Buriro, A.U. and Agha, K.S. (2004). Effect of organic and inorganic fertilizer application on maize fodder production. Asian Journal of Plant Sciences, 3(3), 375-377.

Oduntan, O. Amos, T. T., and Oseni, J. O. (2016). Resource productivity among small scale maize-cowpea farmers in South West, Nigeria: A translog function approach. Asian Journal of Agricultural Extension, Economics \& Sociology, 13(4), 1-10.

Okonmah, L. U. (2009). Effects of various organic manure on the growth and yield of maize in Asaba agroecological zone. Asian Journal of Science and Technology, 4(11), 006-009.

Restuccia, D., and Santaeulàlia-Llopis, R. (2017). Land misallocation and productivity. Barcelona GSE Working Paper Series. Working Paper $n^{\circ} 954$.

Ricker-Gilbert, J. and Jayne, T.S. (2009). Do fertilizer subsidies affect the demand for commercial fertilizer? An Example from Malawi. Contributed Paper prepared for presentation at the International Association of Agricultural Economists Conference, Beijing, China, August 16-22, 2009.

Ricker-Gilbert, J. and Jayne, T.S. (2010). What are the dynamic effects of fertilizer subsidies on household wellbeing? Evidence from Malawi. Contributed Paper presented at the Joint 3rd African Association of Agricultural Economists (AAAE) and 48th Agricultural Economists Association of South Africa (AEASA) Conference, Cape Town, South Africa, September 19-23, 2010.

Ricker-Gilbert, J., Jayne, T.S., and Black, J.R. (2009). Does subsidizing fertilizer increase yields? Evidence from Malawi. Selected Paper prepared for presentation at the Agricultural \& Applied Economics Association 2009 AAEA \& ACCI Joint Annual Meeting, Milwaukee, Wisconsin, July 26-29, 2009.

Sagona, W., C., J., Kachala, O., Matete, S., and Jenya, H. (2016). Physiochemical properties of soil in selected sites of the Lake Chilwa Basin after 5 years of Conservation Agriculture Practice. Universal Journal of 
Agricultural Research, 4(4), 155-164.

Sauer, J., Tchale, H. (2009). The Economics of Soil Fertility Management in Malawi. Review of Agricultural Economics, 31(3), 535-560.

Sheng, Y., Ding, J., and Huang, J. (2019). The relationship between farm size and productivity in agriculture: Evidence from maize production in Northern China. American Journal of Agricultural Economics, 101(3), 790-806.

Shi, H., Wang, X., Xu, M., Zhang, H., Luo, Y. (2017). Characteristics of soil C:N ratio and $\delta 13 \mathrm{C}$ in wheat-maize cropping system of the North China Plain and influences of the Yellow River. Scientific Reports, 7:16854, DOI:10.1038/s41598-017-17060-3.

Sienso, G., Asuming-Brempong, S., Amegashie, D. P. K. (2014). Estimating the efficiency of maize farmers in Ghana. Asian Journal of Agricultural Extension, Economics \& Sociology, 3(6), 705-720.

Simwaka, K., Ferrer, S., and Harris, G. (2013). Analysis of factors affecting technical efficiency of smallholder farmers: Comparing time-varying and time-invariant inefficiency models. African Journal of Agricultural Research, 8(29), 3983-3993.

Smale, M., Heisey, P. W. and Leathers, H. D, (1995). Maize of the ancestors and modern varieties: the microeconomics of high-yielding variety adoption in Malawi. Economic Development and Cultural Change, 43(2), 351-68.

Snapp, S. (no date). A Greener Revolution in Malawi, Next steps toward soil rehabilitation and productivity. Available at: https://agrilinks.org/sites/default/files/resource/files/MalawiGreenRevolution JeopardySnapp.pdf.

Snapp, S., Jayne, T.S., Mhango, W., Benson, T., and Ricker-Gilbert, J. (2014). Maize yield response to nitrogen in Malawi's smallholder production systems. International Food Policy Research Institute. Working Paper 9.

Snapp, S.S. (1998). Soil nutrient status of smallholder farms in Malawi. Communications in Soil Science and Plant Analysis, 29(17\&18):2571-2588.

Stern, I.D. (2008). Elasticities of substitution and complementarity. MPRA. Paper No. 12454.Tchale, H. (2009). The efficiency of smallholder agriculture in http://ageconsearch.umn.edu/bitstream/56909/2/0302Tchale.pdf.

Tchale, H. and Sauer, J. (2007). The efficiency of maize farming in Malawi: A bootstrapped translog frontier. Cahiers d'économieetsociologierurales, $\mathrm{n}^{\circ}$ 82-83.

Whitbread, A., Sennhenn, A., and Grotelüschen, K. (2013). Nitrogen-use-efficiency in maize-based farming systems in Malawi: a simulation study and meta-analysis of literature. University of Goettingen, Grisebachstr. 637077 Göttingen, Germany.

Woldsenbet, M. and Haileyesus, A. (2016). Effect of nitrogen fertilizer on growth, yield and yield components of maize (Zea mays L.) in Decha district, Southwestern Ethiopia. International Journal of ResearchGranthaalayah, 4(2), 95-100. 